\title{
The Relationship of Positive Thinking and Forgiving Behavior in Student's Friendship
}

\author{
Reza Fahmi, Dila Fulnandra, Prima Aswirna \\ Universitas Islam Negeri (UIN) Imam Bonjol Padang, Indonesia \\ rezafahmi@uinib.ac.id
}

\begin{abstract}
The objective of this study was to determine the category of positive thinking and forgiving behavior among the students in their friendship. This research applied a quantitative approach where the data were analyzed by using Pearson Correlation analysis. The subjects of this research were 65 students from 78 students in the populations. The data were collected by using the instrument as regards psychological scales, a modification of the Likert scale. It measured the level of positive thinking forgiving behavior. The results of this study revealed that the boarding school's students at Lubuk Lintah have a low level of positive thinking. Furthermore, the students who live in Heler dorm at LubukLintahalso have a low level of forgiving behavior in which the significance value of positive thinking and forgiving behavior was 0,000 with a Pearson Correlation coefficient of 0.666 .
\end{abstract}

Keywords: Positive Thinking, Heler, Forgiving Behavior

\section{Introduction}

Humans are known as social beings, wherein the process of human development, they cannot be separated from social interaction. In doing so, the condition certainly does not always run smoothly. Some unpleasant things, such as quarrels, conflicts, or making mistakes, possibly occur among the students. Such a thing can hurt one another. As regards social interaction, it is not pleasant if somebody makes mistakes without apologizing. In a similar case, sometimes the mistakes are not forgiven by some students. There is also a case when somebody already apologized but not sincerely forgiven. Forgiveness is the key to break anger and the fetter of hatred towards someone. It breaks the attachment to selfishness.Forgiveness (in Hasan, 2013: 13-14) is socially used as an instrument to block one's desire for revenge. McCullough (in Anggraini and Hijriyati, 2014: 19) suggests that forgiveness can be a set of motivations to prevent someone from revenge and defuse the urge to maintain hatred towards the offending party. Moreover, it increases the possibility to conciliate the relationship with the offending party. A similar opinion was expressed by Wardhati and Faturochman (2019: 3) that forgiveness is a willingness to release of painful mistakes from the past. Forno

AJIS : Academic Journal of Islamic Studies, vol. 5, no. 1, 2020

IAIN Curup - Indonesia | ISSN 2580-3174, (p); 2580-3190 (e)

DOI: $10.29240 / a j i s . v 5 i 1.1370$, page: 
longer looking for the reason of anger and hatred, and dismiss the desire to hurt others or yourself.As human beings, it is undeniable that we have experienced ups and downs in relationships, such as in a friendship. In a close relationship, forgiving (in Utami, 2015: 56) is said as what is wanted and needed by individuals who make mistakes. Forgiveness means removing wounds or scars in the heart; according to Shihab, forgiveness requires a readiness to forgive both requested and not requested.

Price, Ladd, and Hays (in Anggraini and Hijriyati, 2014: 20) define friendship as a relationship where specific social and emotional needs are met. It includes emotional support, task assistance, and intellectual stimulation. According to Hajad (2011: 343), friendship means truly friendship, and he will not last long without being willing to forgive the mistakes of his friends. Friends must be treated in proper ways so that friendship will not break. It also includes maintaining a love for old friends who close in faith.Those attitudes are indicators of the kindness of one's behavior that will be the way to get the trust of others.

Appertaining to unpleasant feelings, some of us maybe have experienced bad treatment from others,such as the students we love. Besides, others may run their days in an environment that continually suppresses and insults their self-esteem.Thus, many factors can cause resentment or unpleasant feeling. It can occur in everybody or every group of people, including the students.

Some students live in groups (dormitories), and some live individually (boarding). The boarding house is a temporary residence. At boarding house, someone can have a lot of friends since a boarding house accepts many students to stay. Therefore, one must be able to adjust to their environment. Unfortunately, self-adjustment certainly does not always run smoothly; there are often problems and mistakes that hurt the heart. Some issues can be overcome entirely,while the otherscannot be finished quickly. In other words, they have not met the agreement towards the problem.

In this study, the researchers focus on the students who live in a boarding house. Kos Heler is one of the boarding houses that is inhabited by the students of UIN Imam Bonjol students. UIN Imam Bonjol students are students who are required to be able to master and live the basic teachings of Islam, namely the Qur'an and Hadith. By learning the pillars and principles of Islam, the students are expected to adjust their behavior to the guidance taught by the sources of Islamic teachings. However, the fact shows that not all of the 
students lived in that boarding house can implement to forgive one's mistakes effortlessly.

Regarding this, one factor that can foster self-forgiving behavior is the ability to think positively. Positive thinking makes a big difference in individual's life because a good and positive attitude starts with positive thinking.Makin \& Lindley (in Nurmayasari and Hadjam, 2015: 9) say that positive thinking is a way that can make someone more positive by evaluating everything by seeing the positive aspects of everything. Positive thoughts will also produce a positive mental attitude that will help individuals to build hopes and overcome discouragement.

Grounded in theforegoing condition as regards positive thinking and forgiving behavior, this research scrutinized whether there is a relationship between positive thinkingand forgiving behavior in friendshipamong the students who lived in Heler (the dormitory).

This study aimed to determine the category of positive thinking and forgiving behavior. Furthermore, it analyze the relationship between positive thinking and forgiving behavior of the students. For the readers, this research is significantin providing information about the relationship between positive thinking and forgiving behavior among the students. Whereas, for boarding's owners, the information will be useful as they need to pay attention to the developments or problems occurred in the boarding students so that harmony can be created among fellow boarders.

\section{Research Methodology}

This research applieda quantitative approach that was defined as a scientific method that has met the scientific principles empirical, objective, measurable, rational, and systematic ( Sugiyono, 2010: 7). The independent variables of this study are positive thinking, while the dependent variable is forgiving behavior. Stratified random sampling was used as the sampling technique. It was done by taking the number of samples in each group that was adjusted to the size of the population. the following table shows the sample in detail:

Table 1: Number of Samples

\begin{tabular}{|l|l|l|}
\hline No & Year of College & Amount \\
\hline 1 & 2013 & 3 students \\
\hline 2 & 2014 & 12 students \\
\hline 3 & 2015 & 15 students \\
\hline
\end{tabular}




\begin{tabular}{|l|l|l|}
\hline 4 & 2016 & 9 students \\
\hline 5 & 2017 & 8 students \\
\hline 6 & 2018 & 18 students \\
\hline & Total & 65 students \\
\hline
\end{tabular}

The populations of this study were the students of Imam Bonjol Padang State Islamic University who live in Heler boarding house with a total of 78 students. The sample were 65 students taken randomly through the Slovin formula.The type of scale used in the study is an ordinal scale with a Likert scale because it is following the purpose of the study to measure the attitude of the subjects related to the variables studied.The measurement scale used in this study is the scale of positive thinking and the level of forgiving behavior. The level of positive thinking is guided by Albercth's theory, which says there are four aspects of positive thinking, namely positive expectations, selfaffirmations, statements that do not assess, and realistic adjustment (in authority, 2007: 155). According to literature reviewed a forgiving behavior scales taken from McCullough's theory that consists of a few A-spec, namely avoidance motivation and revenge motivation (McCulough, 2000: 44).

According to Sekaran (in Priyatno, 2012: 187), the reliability that less than 0.6 is not accepted, while 0.7 is acceptable, and above 0.8 is good. Thus, from the explanation above, the researchers takes the reliability limit of 0.8 . This study used questionnaire as the data collection technique where there were two scales. A range consisting of 80 statement items and level of forgiving behavior consisting of 41 item statements. On each level, there is an identity sheet, an answer column, the instruction, and thank you. Moreover, the researchers used interviews and observations as an initial data collection techniques.

\section{Result and Discussion}

The description of the data were used to categorize variables by classifying the subjects into two categories, namely, high and low. According to Azwar (2005), a scale score as a result of a numerical (quantitative) score requires a norm of comparison to be interpreted qualitatively. Based on these objectives, the researchers determined a categorization according to the following formula.

The above category formula is used as a reference to determine the categories of positive thinking and the categories of forgiving behavior onboarding's students. The following table can illustrate categorization based on the results of these studies. 
Table 2: Categorization of Positive Thinking Scale

\begin{tabular}{|c|c|c|c|c|}
\hline No & Score & Amount & Category & Percentage \\
\hline 1 & $160-201$ & 35 & low & $54 \%$ \\
\hline 2 & $202-242$ & 30 & high & $46 \%$ \\
\hline
\end{tabular}

Source: Research Data

Based on the analysis of the data, it shows that from 65 subjects studied, as many as 35 students or $54 \%$ have low levels of positive thinking, and 30 students or $46 \%$ have high levels of positive thinking. This data indicates that most of the boarding students in LubukLintah are more dominant having a low level of positive thinking.

A student is said to have a low level of positive thinking when inclined to think negatively. Itprevents a person from accepting others' opinions, new things, and socialization. If the negativity is more dominant in one's mind, it can cause prejudice, self-blame, pessimism, distrust and suspicion with no reason at all. Rahardian Sukma (2017: 26) stated that negative thoughts is a collection of wrong ideas that hinder a person's steps from obtaining better conditions and situations and make human behavior not directed. In its form, negative thoughts are not only in ways such as anger, jealousy, or prejudice but also be anxious, scared, sad, anxious, restless, frustrated, feeling lonely, feeling worthless, pessimistic, and quickly give up.

Table 3: Categorization of the Scale of Forgiving Behavior

\begin{tabular}{|c|c|c|c|c|}
\hline No & Score & Amount & Category & Percentage \\
\hline 1 & $87-118$ & 41 & low & $63 \%$ \\
\hline 2 & $119-149$ & 24 & high & $37 \%$ \\
\hline
\end{tabular}

Source: Research Data

Based on the data analysis, it shows from 65 studied subjects, 41 students or $63 \%$ have a low level of forgiving behavior, while 24 students or $37 \%$ have a high level of forgiving behavior. This data indicates that most of the boarding students in LubukLintah are more dominant having a low level of forgiving behavior.

A student has a low forgiving behavior when it tends to be difficult to forgive others because there is still a sense of revenge and anger in his heart that is caused by conflicts that have previously occurred to a person. One of the problems that often occurs is a conflict with roommates. many factors that potentially become a problem such asa picket schedule, borrowing with no 
permission, feel jealous of other friends, offended by way of talking, debts, inappropriate learning habits, and room cleanliness.

As stated by Baumeister (in Sumiati and Stefanus, 2013: 147), one obstacle to give a forgiveness is the inability of the individual to see the possible things that exist in him to do something that should not be against other individuals. Baumeister further explained that the failure to understand that individuals might make mistakes made by other individuals is related to a rougher assessment (not mature) and low readiness to forgive.

Resting upon the data obtained, the researchers can conclude that there is a relationship between positive thinking and forgiving behavior. It can be proven based on the results of data analysis that have been carried out, namely:

\section{Linearity Test}

Linearity test aims to determine whether the two research variables significantly have a linear relationship or not. Both variables are said to be linear if they have a significance level of less than $0.05(\mathrm{P}<0.05)$ (Priyatno, 2014: 79).Based on the linearity test using SPSS version 16.0 for windows, it can be seen that the significance value of linearity is 0.000 and the importance of $F=63.906$. Because the significance is less than $0.05(0.000<0.05)$, it can be concluded that there are a linear relationship between positive thinking variables and forgiving behavior. It refers that the assumption of linearity is fulfilled.

\section{Normality Test}

The normality test aims to determine whether the data population is normally distributed or not. Normal data distribution states that the research subjects are classified as representative or can represent the existing population, preferably if the delivery is not normal, it can be concluded that the issue is not elected or does not represent the current population. The normality test in this study used the one-sample Kolmogorov Smirnov test. It can be stated customarily distributed if the significance is more significant than 0.05 (Priyatno, 2012). Based on data analyzed by using SPSS version 16.0 for windows, the normality test results are as follows. 
Table 4: Test for the Normality of Positive Thinking Scale and Forgiving Behavior

\begin{tabular}{|l|l|l|}
\hline Variable & $\begin{array}{l}\text { Kolmogorov- } \\
\text { Smirnov Z }\end{array}$ & Asymp Sig \\
\hline Positive thinking & 0,769 & 0,596 \\
\hline Forgiving Behavior & 0,766 & 0,601 \\
\hline
\end{tabular}

Source: SPSS Data 16.0 for windows

To know customarily distributed data or not, it can be seen from the table One-Sample Kolmogorov-Smirnov Test in the table above. The test criteria are if the significance value $>0.05$ then the data is normally distributed. From table 4.5 above, it can be seen that the significance value (Asymptotic Significance 2-tailed) for positive thinking is 0.596 , and forgiving behavior is 0.601 . Significance for positive thinking variables is higher than 0.05 , then the normal distribution and for the importance of forgiving behavior is also higher than 0.05 , then the normal distribution. Hence, it can be concluded that the scale of positive thinking scale data is normally distributed, and the behavior scale of forgiveness data is also normally distributed.

\section{Hypothesis testing}

Hypothesis testing is done by using Pearson correlation analysis to determine whether there is a relationship between positive thinking and forgiving behavior. Based on the results by using the SPSS program version 16.0 for windows, the obtained dataare as follows:

Table 5: Test Hypothesis of Positive Thinking Scale Distributionand the Scale of Forgiving Behavior

\begin{tabular}{|l|l|l|}
\hline Variable & $\begin{array}{l}\text { Pearson } \\
\text { Correlation }\end{array}$ & Sig \\
\hline $\begin{array}{l}\text { Positive thinking - forgiving } \\
\text { behavior }\end{array}$ & 0,666 & 0,000 \\
\hline
\end{tabular}

Source: SPSS Data 16.0 for windows

The results of the data analysis in the table above show that the Pearson correlation coefficient value of positive thinking with a forgiving behavior of 0.666 . If the significance value $<0.05$ means the hypothesis is accepted while if the significance value $>0.05$ means the hypothesis is rejected (Prayitno, 2012: 109).The significance of positive thinking and forgiving behavior is 0,000 ( 0 , $000<0.05$ ), so Ha is received. It means that the significance level between the two variables shows the relationship between positive thinking and forgiving behavior. Therefore, it can be concluded that there is a relationship between 
Positive Thinking and Forgiving Behavior in Friendship among Kos Heler Students in LubukLintah. These findings revealed that the higher or lower the level of positive thinking, students would affect the level of forgiving behavior.

\section{Conclusion}

This study proves that there is a significant positive relationship between positive thinking and forgiving behavior among students who live in the Heler dormitory. Itimplies that when positive thinking among students is low, forgiving behavior among students is also low. This findings revealed the need to increased awareness to think positively among students by not prejudicing other students living in the dormitory that could potentially lead to conflict. Then at the same time, there needs to be an effort to increase awareness to forgive among students so that they are not easily offended and more tolerant when they face common problems. Thus, life in the dorm will be more fun and make them able to respect each other as evidence of efforts to create a harmonious life among them.

Then, students must familiarize themselves with seeing positive things in themselves, being friendly, and getting rid of hostility, optimistic looking forward, persistent, diligent, and unyielding. Positive self-assessment will affect the mindset that ultimately leads to positive emotions, positive behaviors, and positive attitudes so that other students can feel and judge, for example, always seeing positive things and mutual respect among students.

For further researchers, positive thinking and forgiving behavior can also be compared across cultures. This research can also be developed through other methodologies, such as experimentsby providing a treatment in how to jump-start positive thinking patterns or forgiving behaviors that have an impact on the welfare of the life of students in particular and humans in general.

At last, the boarding's owners should pay more attention to the relationships and communication between borders as well as sharing about the problems they face. It can be useful to create harmony and be able to guide the boarders when there are problems so that the issues are not protracted and can be appropriately resolved.

\section{References}

Angraini, Dewi dan Hijriyati Cucuani. "Hubungan Kualitas Persahabatan Dan Empati Pada Pemaafan Remaja Akhir". Riau: Universitas Islam Negeri Sultan SyarifKasim Riau. Jurnal Psikologi, Vol. 10. No. 1. 
Azwar, S. 2009. Penyusunan Skala Psikologi. Yogyakarta. Pustaka Pelajar.

Hajjad, Muhammad Fauqi. 2011. Tasawuf Islam Dan Akhlak. Jakarta: Amzah.

Hasan, Aliah B. Purwakania. 2013. "Pemaafan sebagai Variabel Moderator pada Pengaruh Religiusitas dengan Agresi Relasional di Kalangan Mahasiswa Universitas Berbasis Nilai-nilai Islam". Jakarta: Universitas Al Azhar Indonesia. Jurnal Al-Azhar Indonesia Seri Humaniora, Vol . 2. No. 1.

Hardivizon, H. (2017). Metode Pembelajaran Rasulullah SAW (Telaah Kualitas Dan Makna Hadis). Belajea; Jurnal Pendidikan Islam, 2(2), 101-124. doi:http://dx.doi.org/10.29240/bjpi.v2i2.287

Kautsar, E., Damayanti, E., Ismail, I., Ahmad, L., \& Jamilah, J. (2020). Perbandingan Kemampuan Konsentrasi Belajar Setelah Mendengar AlQur'an: Antara Murattal dan Tilawah. AL QUDS : Jurnal Studi Alquran dan Hadis, 4(1), 39-56. doi: http://dx.doi.org/10.29240/alquds.v4i1.1254

Wardhati Latifah Tri \& Faturochman, Psikologi Pemaafan, dalam http://fatur.staff.ugm.ac.id/file/ Psikologi\%20\%20Pemaafan.pdf, hal. 7. Diakses tanggal 27 Juli 2018 pukul 17.30.

McCullough, M.E. 2000. "Forgivennes As Human Strenght: Theory, Measurement, And Links To Well-Being". Journal of social and clinical psychology. Vol 19, No 1.

Nashori, Fuad, "Pemaafan pada Etnis Jawa Ditinjau dari Faktor Demografi:, Jurnal Psikologika Vol 18 No. 2 Tahun 2013.

Nurmayasari, Kiki dan Hadjam, Murusdi. 2015. "Hubungan Antara Berpikir Positif Dan Perilaku Menyontek Pada Siswa Kelas X SMK Koperasi Yogyakarta". Yogyakarta: Universitas Ahmad Dahlan Yogyakarta. Jurnal Fakultas Psikologi Vol. 3. No. 1.

Powell, Russell, "Forgiveness in Islamic Ethics and Jurisprudence", Berkeley Jurnal of Middle Eastern and Islamic Law, Vol. 4:1, 2012.

Priyatno, Duwi. 2012. Cara Kilat Belajar Analisis Data dengan SPSS 20. Yogyakarta: Andi.

Sudak, D. M. (2012). "Cognitive behavioral therapy for depression. Psychiatric Clinics”, 35, 99-110. https://doi.org/10.1016/j.psc.2011.10.001

Sugiyono. 2011. Metode penelitian kuantitatif, kualitatif dan R\&D. Bandung: Alfabeta. 
Sukma, Rahardian. 2017. Move on dari Pikiran Negatif. Yogyakarta: Serambi Semesta Distribusi.

Sumiati, Ilsan dan Stefanus Soejanto Sandjaja. 2013. "Hubungan Antara Memaafkan Dengan Kematangan Diri Pada Remaja Akhir". Universitas Kristen KridaWacana. Jurnal NOETIC Psychology. Vol.3. No. 2 .

The Pursuit of Happiness. (n.d.). http://www.pursuit-ofhappiness.org/history-ofhappiness/william-james/Toussaint, L. L., Owen, A. D., \& Cheadle, A. (2012). "Forgive to live: Forgiveness, health, and longevity". Journal of Behavior Medicine, 35, 375386.http://dx.doi.org/10.1007/s10865-011-9362-4

Toussaint, L. L., Shields, G. S., Dorn, G., \&Slavich, G. M. (2016). "Effects of lifetime stressexposure on mental and physical health in young adulthood: How stress degrades andforgiveness protects health". Journal of Health Psychology, 21, 10041014.https://doi.org/10.1177/1359

Toussaint, L. L., Shields, G. S., \&Slavich, G. M. (2016). "Forgiveness, stress, and health: A 5-week dynamic parallel process study. Annals of Behavioral Medicine", 50, 727-735.https://doi.org/10.1007/s12160-016-9796-6

Toussaint, L. L., Vincent, A., McAllister, S. J., Oh, T. H., \& Hassett, A. L. (2014). "A comparison affect balance styles". Scandinavian Journal of Pain, 5, 161166.http://dx.doi.org/http://dx.doi.org/10.1016/j.sjpain.2014.05.001

Utami, DeassyArifianti. 2015. "Kepercayaan Interpersonal Dengan Pemaafan Dalam Hubungan Persahabatan:. Universitas Muhammadiyah Malang.. Vol. 03. No. 01.

Wibawa, Lutfi. 2007. "Pelatihan Berpikir Positif Bagi Remaja Putus Sekolah". Universitas Negeri Yogyakarta. Jurnal Pendidikan Luar Sekolah. Vol 6, No 11.

Worthington, Jr, E. L. (2013). Moving forward: Six steps to forgiving yourself and breaking freefrom the past. Colorado Springs, CO: WaterBrook Press.

Worthington, Jr, E. L., Wade, N. G., \& Hoyt, W. T. (2014). "Positive psychological interventionsfor promoting forgiveness". In A. C. Parks \& S. M. Schueller (Eds.), The Wiley Blackwell hand book of positive psychological interventions (pp. 20-41). Malden, MA: John Wiley\& Sons. 